SYMBOLAE PHILOLOGORUM POSNANIENSIUM GRAECAE ET LATINAE XXVI/1 • 2016

pp. 109-121. ISBN 978-83-232-3059-5. ISSN 0302-7384

DOI: $10.14746 /$ sppg1.2016.XXVI.1.6

\title{
ŁUKASZ BERGER
}

Katedra Filologii Klasycznej Uniwersytetu Śląskiego w Katowicach pl. Sejmu Śląskiego 1, 40-032

Polska - Poland

\section{SENEKA, APOCOLOCYNTOSIS 1-4 „ŚMIERĆ BOSKIEGO KLAUDIUSZA”}

ABSTRACT. Berger Łukasz, Seneka, Apocolocyntosis 1-4 „Śmierć Boskiego Klaudiusza” (Seneca, Apocolocyntosis 1-4 „The Death of the Divine Claudius”).

The paper consists of a new Polish translation of the initial part of Apocolocyntosis (1-4) by Seneca the Younger with a short introduction, notes and a commentary.

Keywords: Apocolocyntosis, Claudius, Seneca the Younger, depiction of death, satire.

\section{WSTĘP}

„Apocolocyntosis czyli Udynienie Boskiego Klaudiusza” to szczególne dzieło w dorobku Seneki Młodszego, słynącego głównie z twórczości filozoficznej, moralizatorskiej i tragediowej. Utwór ten, napisany w konwencji satyry menippejskiej ${ }^{1}$, miał być bezpośrednią reakcją autora na śmierć znienawidzonego cesarza (13 października 54 r.), który ongiś zesłał go na Korsykę. Jeśli uznać Apocolocyntosis za rodzaj nieprzebierającej w środkach literackiej zemsty, byłby to akt tym okrutniejszy, że dokonany na nieżyjącym wrogu. $Z$ drugiej strony, gniew i poczucie urazy, z którymi może wiązać się geneza utworu, nie przystają do głoszonego przez Senekę w dialogach ideału stoickiego mędrca ${ }^{2}$. Całkiem zrozumiałym zabiegiem jest natomiast połączenie sparodiowanej apoteozy i rozbudowanej damnatio memoriae Klaudiusza z pochwałą jego następcy - obejmującego władzę młodego Nerona. W ten sposób pisarz musiał odzwierciedlać nastroje i oczekiwania ówczesnych elit społecznych ${ }^{3}$.

Jeśli jednak pozostawić, w dużej mierze nierozwiązane, kwestie genezy utworu oraz jego przesłania ideologicznego, może okazać się, że wymiar ar-

\footnotetext{
${ }^{1}$ Cf. Korus 1990, Wołek 2011.

${ }^{2}$ Wesołowska 2004.

${ }^{3}$ Cortés Tovar 1986: 289.
} 
tystyczny Apocolocyntosis jest dużo ważniejszy od politycznego. Wiele cech - miejscami teatralnego - języka satyry wskazuje bowiem na jego recytowanie viva voce $\mathrm{w}$ formie, która może przypominałaby współczesne popisy kabaretowe w stylu stand-up comedy ${ }^{4}$. Potencjał humorystyczny całości dziełka jest przy tym ściśle powiązany z tradycją gatunkową satyry menippejskiej. Riikonen do opisu karnawałowej estetyki Apocolcyntosis używa Bachtinowskiego terminu wielogłosowości (polyglossia) ${ }^{5}$. Całe dzieło przybiera wszak iście proteuszową formę, łączącą różne zestroje komunikacyjne (monolog narratora, dialog z odbiorcą, sermocinatio), nawiązania intertekstualne (cytaty, parodie, aluzje), kody artystyczne (wiersz, proza) i rejestry języka (oficjalny, kolokwialny ${ }^{6}$, wulgarny). Bez większej przesady można zatem powiedzieć, że wielogłosowość satyry Senecjańskiej dotyczy właściwie wszystkich jej poziomów kompozycyjnych.

Niestety, dostępny polskiemu czytelnikowi przekład jedynie w niewielkim stopniu oddaje różnorodność języka i komizm Apocolocyntosis ${ }^{7}$, który okazuje się dużo bardziej wyszukany, niż można by sądzić po pobieżnej lekturze zarówno oryginału Seneki, jak i tłumaczenia L. Joachimowicza. Naszym zamiarem była zatem próba odzyskania tego, co - jak śmiemy twierdzić - zostało stracone lub nie wybrzmiało z wystarczającą mocą przy ostatnim spolszczeniu, ponad pół wieku temu. W tym celu wybraliśmy sam początek satyry, obejmujący wstęp narratora oraz agonię boskiego Klaudiusza (Apoc. 1-4), który z powodzeniem można uznać za zamkniętą całość, pod wieloma względami stanowiącą ramę kompozycyjną utworu 8 .

Priorytetem w prezentowanym poniżej przekładzie jest komunikatywność, która z założenia powinna ułatwić nawiązanie bliskiej relacji z odbiorcą, kluczowej dla wywołania efektu komicznego. Oprócz odświeżenia warstwy leksykalnej i frazeologicznej takie podejście wiąże się z pewnym uproszczeniem składni oryginału łacińskiego. Dodatkowo staraliśmy się wyróżnić miejsca, które - jak wskazują współcześni komentatorzy i interpretatorzy dzieła - są zabarwione

${ }^{4}$ Eden (1984: 13), autor jednego z komentowanych wydań utworu, pisze we wstępie wprost o miming recital (cf. komentarz do Apoc. 1.1, 1.3, 5.1 oraz passim). Coffey (1989: 169-177) teorię o „wystawieniu” dzieła Seneki, na przykład na Neroneia, uważa za mało prawdopodobną, ale również przypisuje mu cechy parateatralnego performance'u. O dramatycznej kompozycji całej satyry, z widocznym podziałem na akty, pisze Korzeniewski (1982).

${ }^{5}$ Riikonen 1987.

${ }^{6} \mathrm{O}$ strategiach stylizowania języka Apocolocyntosis na sermo cotidianus pisaliśmy szerzej w Berger 2012.

${ }^{7}$ Nie miejsce tutaj na krytyczną analizę tłumaczenia L. Joachimowicza, choć można wspomnieć o niekonsekwencji w tłumaczeniu partii wierszowanych, nieuzasadnionym użyciu archaizmów lub neologizmów oraz braku wyraźnego stylizowania poszczególnych sermocinationes. Mała komunikatywność niektórych passusów wiąże się oczywiście z naturalnym procesem „starzenia się" polskiego przekładu.

${ }^{8}$ Korzeniewski 1982. 
dużą dozą ironii i sarkazmu. Dotyczy to także gier słownych, double entendre i zaskakujących point. Stąd pewne rozwiązania typograficzne, takie jak użycie tekstu rozstrzelonego, dywizu lub wielokropka, które należy traktować jako wskazówki do odczytania tekstu viva voce. Zgodnie z tym, o czym pisaliśmy już wyżej, przy lekturze Apocolocyntosis uważny czytelnik w końcu przekonuje się, że wiele z humorystycznej warstwy dzieła można docenić dopiero podczas aktualizacji tekstu „pisanego” za pomocą wprawnego głosu recytatora9

Oczywiście, trudno w ten sposób oddać złożoność każdego passusu - w wielu miejscach elementy parodystyczne oraz aluzje polityczne lub literackie są zrozumiałe dla współczesnego odbiorcy jedynie dzięki informacjom zawartym w przypisach dolnych, które z tego powodu zdecydowaliśmy się znacząco rozszerzyć. Poniżej natomiast zamieszczamy krótki komentarz uwzględniający najnowsze naukowe opracowania Apocolocyntosis i dostarczający - mamy nadzieję - dodatkowych kontekstów do interpretacji Senecjańskiej satyry. W ten sposób chcieliśmy zasugerować trzy możliwe modele odbioru dzieła: (1) bezpośredni, oparty jedynie na spolszczonym tekście głównym oraz performatywnych kompetencjach czytelnika-wykonawcy; (2) poszerzony o realia i bazę faktograficzną w przypisach; (3) filologiczny, odwołujący się do szerszego kontekstu historyczno-literackiego i interpretacji zaproponowanej w komentarzu poniżej.

$$
* * *
$$

\section{KOMENTARZ (Sen. Apoc. 1-4)}

[Apoc. 1] Satyra na śmierć Klaudiusza rozpoczyna się od jednoosobowego wstępu, w którym narrator kreuje się na dziejopisarza. Już w pierwszych zdaniach następują ekspozycja tematu, podkreślenie historiograficznej obiektywności i rzetelności źródeł. Powaga przekazu wiekopomnych wydarzeń (Apoc. 1.1: memoriae tradere) zostaje natychmiast zastąpiona dowcipnym dialogiem $\mathrm{z}$ odbiorcą, naznaczonym zwrotami bezpośrednimi i wyrażeniami potocznymi, za których pośrednictwem w przestrzeni komunikacyjnej dzieła narasta atmosfera nieformalnej intymności. Nie można wszak poważnie traktować historiografa, który zapowiada bezstronność przekazu, a kilka linijek niżej nazywa Klaudiusza głupcem, tyranem i kuternogą. Narrator wielokrotnie zapewnia o rzetelnych podstawach swej relacji, choć później bezczelnie wyznaje, że wszystkie informacje równie dobrze mogą być wyssane z palca lub - w najlepszym wypadku - zasłyszane na osobności od jedynego świadka, doświadczającego wątpliwych wizji na środku drogi. Niekonsekwencja zarówno w stylu, jak i w przesłaniu pierwszego rozdziału obala ostatecznie historiograficzne pretensje dziełka i wprawnie

\footnotetext{
${ }^{9} \mathrm{~W}$ pierwszych wiekach cesarstwa publiczne recytowanie tekstów literackich było podstawową formą rozpowszechniania i aktualizowania tekstów kultury (Kenney 2008). Dowody na popularność recitatio w czasach Seneki przedstawia m.in. Pliniusz Młodszy (Ep. 3, 5.12).
} 
wpisuje całą narrację w tradycję pseudohistorii oraz opowiastek fantastycznych w duchu Lukiana (cf. Ver. hist. 1.4).

[Apoc. 2] Po ironicznych nawiązaniach do stylu dzieł historycznych satyra Seneki zwraca się w stronę zmanierowanych poetów. Peryfrastyczny opis pory roku, dnia i godziny śmierci Klaudiusza jest parodią literackiego cliché, charakterystycznego dla epiki (cf. Verg. Aen. II 8-9, IV 522-5, VIII 26-7). Jako że dokładna data omawianych wydarzeń została już podana z precyzją historiografa (Apoc. 1.1), głównym celem autora jest tutaj raczej krytyka pompatycznego stylu w poezji, którą wyraził także w jednym z listów do Lucyliusza, gdzie niejaki Juliusz Montantus (tolerabilis poeta) nadużywał w swoich wierszach podobnych chwytów (Ep. 122. 11-13: ortus et occasus libentissime inserebat $)^{10}$.

[Apoc. 3] Dość nagłe pojawienie się w tekście boskiego posłańca sugeruje niezapowiedzianą zmianę miejsca akcji i przeniesienie się na plan fantastyczny (Olimp). Rozmowa między Merkurym a jedną z Parek staje się preludium do śmierci Klaudiusza, swoistą retardacją akcji, która w planie rzeczywistym nakłada się na jego wydłużoną agonię, opisaną przez Swetoniusza (Claud. 44.3). Obecność Merkurego, niecierpliwie czekającego na zgon Klaudiusza, tak tutaj, jak i w dalszej części utworu należy tłumaczyć jego funkcją przewodnika dusz (Apoc. 11.6). Dodatkowo jednak chyży i wymowny bóg podstępu (Hor. Carm. I 10.1-4) funkcjonuje w tej początkowej części satyry jako antypatron przygłupiego, jąkającego się i kulejącego Klaudiusza - stąd ironia w słowach Merkurego, „lubującego się we wrodzonych zdolnościach (ingenia)” cesarza. Pogardliwy stosunek boga do protegowanego kontrastuje ze sposobem, w jaki w kolejnym rozdziale będą układały się relacje Nerona z jego patronem Apollonem. Scena na Olimpie jest ponadto pierwszą okazją do wprowadzenia dłuższych sermocinationes. Wprawny stylista Seneka wykorzystuje ją do językowej charakterystyki starej Kloto, której każe zaprezentować się w postaci lekko zdziecinniałej staruszki, nadużywającej emocjonalnych zdrobnień, co w sposób humorystyczny kontrastuje z obcesowym i „męskim” (cf. Gel. NA. XI 6) wykrzyknieniem mehercules!

Kiedy Parka wreszcie decyduje się spełnić prośbę Merkurego, by „ulżyć” Klaudiuszowi i całemu państwu w cierpieniach, tekst satyry niepostrzeżenie przechodzi w mowę wiązaną.

[Apoc. 4] Oto epickie heksametry ilustrują moment przecięcia linii żywota obśmiewanego cesarza, by natychmiast wprowadzić pochwałę Nerona, zapowiadającą jednocześnie nadejście złotego wieku (aurea aetas), który ma towarzyszyć jego wstąpieniu na tron (cf. Verg. Aen. VI 792 nn., Ecl. 4). Obraz budzącej się przyrody wyraźnie kontrastuje tutaj z treścią zawartą w poprzednich partiach poetyckich: świata przygotowującego się do zimy (Apoc. 2.1) oraz opisu godzin popołudniowych (2.4). Śmierci Klaudiusza towarzyszy różnorako rozumiana schyłkowość - panowanie Nerona to wielkie odrodzenie.

\footnotetext{
${ }^{10} \mathrm{Cf}$. o peryfrazie w stylu poetyckim Quint. Inst. VIII $6.59 \mathrm{nn}$.
} 
Eden z niemałą przenikliwością zauważa, że - nawet jeśli w tej części utworu brak elementów satyrycznych - sztampowość heksametrów o przeciętnej wartości artystycznej nie osiąga spodziewanego efektu ${ }^{11}$. Trudno mówić o prawdziwej laudatio, skoro została celowo wystylizowana na dzieło pośledniego poety epickiego, raczej o statusie rzemieślnika niż wieszcza ${ }^{12}$. Z drugiej strony, wymowa passusu zgadza się z nadziejami wiązanymi z rządami młodego Nerona także w innych, pod tym względem bardziej „,natchnionych” utworach z epoki (Calp. Ecl. 1.42 nn., 1.71 nn., 4.137 nn., Buc. Eins. 2.21 nn., Luc. I 33 nn.). Możliwe więc, że za sztampowym potraktowaniem tego motywu kryje się pesymizm Seneki, który w mocno zawoalowany sposób odrobiną sarkazmu częstuje także swego wychowanka i jednocześnie nowego władcę cesarstwa. Ponadto satyryk, poświęcając tyle uwagi poetyckim rzemieślnikom, mógł tutaj przemycić aluzję do niskiej oceny działalności literackiej Nerona.

Powrót do prozy jest równie nagły jak zmiana rejestru języka: z poetyckiego na potoczny. Eliptyczne haec (ait) Apollo wraz z poprzedzającą je formułą zamknięcia wypowiedzi Kloto (Apoc. 4.1: haec ait et ...) tworzą stylistyczną klamrę pomiędzy dwoma różnymi kodami języka. Przeskok ten jest tym bardziej wyczuwalny, że koniec tego rozdziału, powrót na ziemski plan narracji, naznaczono nie tylko wieloma kolokwializmami, lecz także serią obrazów o charakterze skatologicznym. Już samo określenie animam ebullit (,wyzionął [właściwie: wybąblił] ducha") jest bardziej potoczną i dysfemiczną wersją eleganckiego wyrażenia animam efflare / exhalare. Sam frazeologizm niesie ze sobą drastyczny i dużo konkretniejszy obraz, który scholiasta Persjusza (2.9-10) tłumaczy podobieństwem między oddaniem ostatniego oddechu (exprirare) a pękającymi bąbelkami powietrza (bullae), uwalniającymi się przy opróżnianiu butelki (ad Pers. 2.9-10: quae [scil. bullae] cum in aqua fiunt, cadentibus guttis rumpuntur et spiritum quo continentur amittunt).

Naturalizm animam ebullire i nacisk na techniczne aspekty konania odsyłają nas do wcześniejszego dosłownego rozumienia zwrotu invenire exitum (Apoc. 3.1) - nareszcie dusza Klaudiusza znalazła ujście i zostawiła jego ciało równie gwałtownie jak rozpadające się bullae. Dźwięk, który towarzyszy takim pękającym bąbelkom gazu, mógł dodatkowo być aluzją do problemów gastrycznych cesarza. Na tym jednak nie koniec - wszystkie skatologiczne okoliczności śmierci cesarza zostaną przez Senekę wykorzystane do jeszcze bardziej zajadłego ataku.

Kiedy mowa o ostatnim słowie (ultima vox) cesarza, autor zmyślnie łączy dwie najbardziej krępujące przypadłości Klaudiusza: jego problemy z artykulacją

\footnotetext{
${ }^{11}$ Eden 1984: 75.

${ }^{12}$ Wesołowska (2004: 196) również sygnalizuje pewien brak konsekwencji w umieszczaniu obok siebie tak zajadłej i ironicznej krytyki Klaudiusza obok pompatycznej pochwały Nerona. Badaczka uznaje to jednak za niezamierzony efekt komiczny, podyktowany wymogami gatunkowymi satyry menippejskiej.
} 
(Suet. Claud. 30: lingua titubantia) oraz wspomniane wyżej dolegliwości gastryczne. Inspiracją dla dowcipu musiał być planowany przez cesarza edykt pozwalający puszczać ze względów zdrowotnych bąki na publicznych bankietach (Suet. Claud. 32) ${ }^{13}$. Oto karykaturalna postać władcy, który nie potrafi „uwolnić” własnych słów, choć przyzwala na ,uwalnianie” gazów. Cesarski anus (= illa pars) nawet na łożu śmierci pozostaje sprawniejszym narzędziem groteskowej „komunikacji” z otoczeniem.

Cała scena staje się zatem kulminacją serii obrazów opisujących trudności $\mathrm{z}$ wydostaniem się z ciała Klaudiusza anima, która nie potrafi znaleźć ujścia, po czym wydostaje się równie gwałtownie, co głośno - niczym bąbelki powietrza. W każdym wypadku sugestywna frazeologia mogła zawierać „niewinne” aluzje do analogicznych procesów fizjologicznych (concretum pro abstracto). Konsekwentne nawiązywanie do flatus ventris oraz ciągłe bazowanie na double entendre sugerują jednak, że satyryk miał na myśli raczej ten skatologiczny aspekt fizjologii ${ }^{14}$. Kiedy umierającemu cesarzowi wreszcie uda się wyartykułować swe przedśmiertne słowa, ich jedyną motywacją i treścią będzie właśnie wypróżnienie kiszek (Apoc. 4.3: „vae me, puto, concacavi me”), a głównym akompaniamentem - głośne uwalnianie gazów ${ }^{15}$.

Całe to nieprzyjemne zdarzenie, jeśli wierzyć relacji Tacyta (Ann. XII 67), mogło mieć potwierdzenie w rzeczywistości, skoro opróżnienie kiszek (soluta alvus) zniwelowało działanie pierwszej dawki trujących grzybów (cf. wymioty i zabieg lewatywy u Suet. Claud. 44.2). Seneka wprowadza ten makabryczny obraz do swojej satyry i podporządkowuje go własnym celom artystycznym, utrzymanym zresztą w estetyce gatunku. Concacatio stwarza także nieprzyjemną scenerię śmierci Klaudiusza, której sposób wedle myśli starożytnych jest zgodny z charakterem postaci za życia ${ }^{16}$. Na koniec wraca głos narratora-hi-

${ }^{13}$ Echa tej legislacyjnej ekstrawagancji odnajdujemy później na uczcie u Trymalchiona (Petr. Sat. 47.1-6).

${ }^{14}$ Puszczanie gazów jest nierzadko motywem literackim (Plaut. Poen. 609), a nawet funkcjonuje jako synonim czegoś błahego (Min. Felix, 28.9). Seneka w listach do Lucyliusza przytacza cynickiego filozofa Demetriusza, który przyrównuje tę czynność fizjologiczną do gadaniny głupca (Ep. 91.4: eleganter Demetrius noster solet dicere eodem loco sibi esse voces inperitorum, quo ventre redditos crepitus). W scenie ostentacyjnego puszczania bąków przez Koraksa (na zmianę z Gitonem - Petr. Sat. 117.12) komentatorzy rozpoznają nie tylko bezpośrednie nawiązanie do Arystofanesa (Ran. 5-18), lecz także możliwą aluzję do braku smaku w rzymskich mimach za czasów Petroniusza. Złośliwy przytyk do gastrycznych przypadłości Klaudiusza w satyrze Seneki wydaje się zatem zasadzać nie tylko na prostej obsceniczności.

${ }^{15}$ Athanassakis (1973: 293-4) w takim kontekście proponuje reinterpretować ulgę, którą na prośbę Merkurego miała przynieść Klaudiuszowi Kloto, oraz prawdziwą przyczynę obrzydliwego wyglądu nici jego żywota (Apoc. 4.1: turpi ... fuso).

${ }^{16}$ Tyberiusz zmarł w osamotnieniu (Suet, Tib. 73.2), Kaligula został ugodzony w lędźwie (Cal. 58.3), podczas gdy Oktawian August zmarł spokojne w objęciach Liwii (Aug. 99). Literacką inwencję Seneki można jeszcze podeprzeć słowami Tacyta opisującego śmierć Tygellina (Hist. I 72.3: infamen vitam foedavit etiam exitu sero et inhonesto). 
storiografa: ten, który przed chwilą tak wiernie oddaje ostatnie słowa konającego (wraz z towarzyszącymi im odgłosami fizjologicznymi), nagle symuluje niepewność, by dać podstawę dla kulminacyjnego dla całego epizodu dowcipu. Seneka w komentarzu do przytaczanej ultima vox zastępuje dosłowne rozumienie przedśmiertnego gastrycznego ,incydentu” Klaudiusza przenośnym i wulgarnym znaczeniem (con)cacare (= 'zniweczyć', 'spartolić'). W ten sposób nie tylko zwięzła i dobitna pointa podsumowuje nieudolne - w ocenie utworu rządy cesarza, lecz także mocnym skatologicznym akcentem kończy się scena śmierci boskiego Klaudiusza.

\section{BIBLIOGRAFIA}

Athanassakis 1973: A. Athanassakis, Some Thoughts on Double-entendres in Seneca Apocolocyntosis 3 and 4, „Classical Philology” 68.4 (1973), 292-294.

Berger 2012: Ł. Berger, Rasgos del lenguaje coloquial en Apocolocyntosis de Séneca el Joven, „Symbolae Philologorum Posnaniensium Graecae et Latinae”, 22.2 (2012), 5-22.

Coffey 1989: M. Coffey, Roman Satire, London 1989.

Cortés Tovar 1986: R. Cortés Tovar, Teoría de la sátira. Análisis de «Apocolocyntosis» de Séneca, Cáceres 1986.

Eden 1984: Seneca. Apocolocyntosis, P.T. Eden (ed.), Cambridge 1984.

Kenney 2008: E.J. Kenney, Books and readers in the Roman world, [w:] The Cambridge History of Classical Literature. Vol. 2. Latin Literature, idem \& W.V. Clausen (ed.), Cambridge University Press, Cambridge 2008.

Korus 1990: K. Korus, Wokót teorii satyry menippejskiej, „Eos” 78 (1990), 119-131.

Korzeniewski 1982: D. Korzeniewski, Senecas Kunst der dramatischen Komposition in seiner Apocolocyntosis, „Mnemosyne” 35.1/2 (1982), 103-114.

Riikonen 1987: H.K. Riikonen, Menippean Satire as a Literary Genre: with special reference to Seneca's Apocolocyntosis, Helsinki 1987.

Wesołowska 2004: E. Wesołowska, Niewesoła zemsta w Apocolocyntosis Seneki, „Classica Wratislaviensia” XXIV, Wrocław 2004, 191-200.

Wołek 2011: A. Wołek, Individual features of Seneca’s Menippean satire, „Classica Cracoviensia” 14 (2011), 391-408.

Wybrane przekłady na języki europejskie

Lucjusz Anneusz Seneka. Apocolocynthosis czyli Udynienie Boskiego Klaudiusza, przeł. L. Joachimowicz, [w:] R. Graves, Klaudiusz i Messalina, Warszawa 1958, [w:] Seneka. Pisma filozoficzne 2, Warszawa 1965.

Lucio Anneo Seneca. Apocolocyntosis, przeł. R. Mugellesi, Milano 1996.

L. Annaeus Seneca. Apocolocyntosis. Die Verkürbissung des Kaisers Claudius, przeł. A. Bauer, Stuttgart 1981.

Sénèque. L'apothéose satirique du divin Claude, przeł. M. Dubuisson, Lovaina 1999 (tekst dostępny na stronie: http://bcs.fltr.ucl.ac.be).

Sèneca. Sàtira de la mort de Claudi (Apocolocintosi), przypisy i przekład S. Giralt Soler, wstęp M. García Sánchez, Barcelona 2002. 
Wykorzystane komentarze

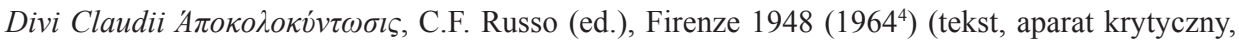
komentarz, przekład wł.).

Séneca. Apocolocyntisis, J. Gil (ed.), [w:] Estudios clásicos. Suplementos II 4, Madrid 1971, 115 203 (tekst, aparat krytyczny, komentarz, przekład hiszp.).

Seneca. Apocolocyntosis, P.T. Eden (ed.), Cambridge 1984 (tekst, aparat krytyczny, komentarz, przekład ang.).

L. Annaeus Seneca. Apocolocyntosis Divii Claudii, A.A. Lund (ed.), Heidelberg 1994 (tekst, aparat krytyczny, komentarz, przekład niem.).

"Naukowe opracowanie wstępu, przypisów i komentarza było możliwe dzięki stypendium przyznanemu przez Fundację z Brzezia Lanckorońskich, za które autor przekładu serdecznie dziękuje.

$* * *$

TŁUMACZENIE: APOCOLOCYNTOSIS $1-4^{17}$

1. [1] Chciałbym tutaj przekazać potomnym, jak się sprawa potoczyła na Olimpie trzynastego października nowego roku, kiedy to nastał wiek pomyślności $^{18}$. Nie będzie w tym ani krzty złośliwości czy pochlebstwa. Ot, sama prawda. Kiedy ktoś będzie dociekał, skąd mam takie informacje, to po pierwsze - jeśli nie będę miał ochoty - nie odpowiem. Kto mnie przymusi? Ja wszak wiem, że jestem wolnym człowiekiem. Jestem wolny, odkąd dopełnił swych dni ten, kto udowodnił prawdziwości przysłowia, że ,albo królem, albo głupcem trzeba się urodzić". [2] A jeśli najdzie mnie ochota odpowiedzieć, powiem, co mi tylko przyjdzie do głowy. Czy ktoś kiedyś wymagał, by świadkowie pod przysięgą ręczyli za historyka? No ale jeśli będzie już trzeba jakiegoś świadka przyprowadzić, kto ciekaw, niech wypyta człowieka, który widział Druzyllę ${ }^{19}$, jak wstępowała na niebiosa. On potwierdzi ${ }^{20}$, że widział Klaudiusza, który „nierównym

${ }^{17}$ Tekst tłumaczenia zasadza się na wydaniu L. Annaei Senecae Apokolokyntōsis, (ed.) R. Roncali, B.G. Teubner, Leipzig 1990 (z niewielkimi korektami zgodnie z sugestiami poszczególnych komentatorów).

${ }^{18}$ „Nowy rok” ma tutaj znaczenie metaforyczne i podkreśla odnowę dziejów wraz ze śmiercią Klaudiusza (13 października 54 r.) i rozpoczęciem panowania Nerona. Literacki topos złotego wieku w kontekście rządów młodego cesarza powróci jeszcze w przemowie Apollona (Apoc. 4).

${ }^{19}$ Julia Druzylla (ur. 17 r.) była córką Germanika i Agrypiny Starszej. Choć dwukrotnie wychodziła za mąż, miała (wedle przekazu Swetoniusza) od dzieciństwa utrzymywać kontakty seksualne ze swoim bratem, późniejszym cesarzem Kaligulą. Po śmierci w 38 r. została ogłoszona przez niepocieszonego władcę boginią.

${ }^{20} \mathrm{~W}$ całym passusie chodzi o senatora Liwiusza Gemin[i]usza, który zeznał pod uroczystą przysięgą w senacie, że był naocznym świadkiem wstąpienia Druzylli w poczet bóstw (Dion, 59.11.4), za co został odpowiednio wynagrodzony. Wizji ubóstwienia Oktawiana Augusta miał doświadczyć niejaki Numeriusz Attykus (Swetoniusz, Aug. 100.4), podczas gdy Juliusz Prokulus miał być świadkiem ascensus Romulusa (Liwiusz, I 16.5 nn.). 
krokiem" ${ }^{21}$ przebył tę samą drogę. Chce czy nie chce - jego uwagi nie ujdzie nic $\mathrm{z}$ tego, co się dzieje na Olimpie: $\mathrm{z}$ urzędu sprawuje przecież pieczę nad Via Appia $^{22}$, którędy - jak wiesz - i boski August, i cezar Tyberiusz szli prosto do bogów $^{23}$. [3] Jeśli jego podpytasz, opowie ci, ale tylko na osobności - przy świadkach nigdy pary z ust nie puści. Kiedyś bowiem zeznawał w senacie, że widział Druzyllę wstępującą na niebiosa i, chociaż to była wspaniała wiadomość, a on zaklinał się na wszystkie świętości - nikt mu nie uwierzył. Odtąd poprzysiągł, że nie złoży już oficjalnego doniesienia, nawet gdyby zobaczył na środku forum ofiarę morderstwa. To, co od niego wtedy usłyszałem, powtarzam wiernie co do joty - tak mu dopomóżcie bogowie!

2. [1] Już Feb, swój kurs skracając, zmniejszył słońca obieg.

Snu też ciemnego pora rosła dłuższa $\mathrm{w}$ dobie.

Już i Kyntia w tryumfie zwiększała swe włości ${ }^{24}$.

Szpetna Zima niszczyła dowody świetności

sutej Jesieni, kiedy z musu Bakch dojrzewał,

ostatnie rwano grona wiszące na krzewach.

[2] Bardziej zrozumiałym będzie chyba, jeśli powiem: był październik, trzynastego. Godziny dokładnej już nie mogę ci powiedzieć: prędzej nastanie zgoda między filozofami niż zegarami ${ }^{25}$. Było w każdym razie między dwunastą w południe a pierwszą. [3] ,Zbyt banalnie! - powiesz - Wszyscy poeci, niezadowoleni z opisywania wschodów i zachodów słońca, są targani takim twórczym nie-

${ }^{21}$ Cytat z Wergiliusza (Aen. II 723-4: ,„dextrae se parvus Iulus / implicuit sequiturque patrem non passibus aequis"). Słowa odnoszą się do dziecięcych kroków Julusa w porównaniu do chodu jego ojca, Eneasza. Tutaj złośliwa aluzja do kalectwa Klaudiusza, kulejącego na jedną nogę, o „nierównym” chodzie (Swetoniusz, Claud. 21.6, 30.1).

${ }^{22} \mathrm{~W}$ czasach republikańskich opiekę nad Via Appia, główną arterią komunikacyjną Rzymu, sprawowali cenzorzy. Za swego panowania August przeniósł obowiązek konstrukcji i utrzymania dróg na nowy urząd zarządców miejskich (curatores). Zajmowali się oni także pracami publicznymi, dostawą wody oraz kontrolowaniem Tybru. Liwiusz Gemin[i]usz sprawował taki właśnie urząd, z czego możemy wnosić, że był blisko dworu cesarskiego.

${ }^{23}$ Jako że obaj władcy zmarli w Kampanii, ich ciała zostały przetransportowane do Rzymu wzdłuż Via Appia. Choć Tyberiusz nie dostąpił po śmierci podobnych boskich honorów jak Oktawian, drogę tę Seneka traktuje jako symboliczny szlak prowadzący na Olimp.

${ }^{24}$ Przydomek Artemidy (Diany), pojawiającej się tutaj jako bogini lunarna. Artemida, podobnie jak jej brat bliźniak Apollo, urodziła się na górze Kyntos na wyspie Delos - tam też ponoć miała swą siedzibę (vide Eurypides, IT 1097-8). Skoro wydłużają się godziny nocne, światło Księżyca trwa dłużej od blasku słonecznego - stąd „zwycięstwo” Artemidy-Kyntii.

${ }^{25} \mathrm{~W}$ starożytności używano dwóch rodzajów zegarów (horologium): słonecznych (solarium) oraz wodnych (klepsydra). Oba urządzenia były mało precyzyjne, choć w tym miejscu Seneka zdaje się raczej nawiązywać do kontrowersji związanych z właściwą godziną śmierci Klaudiusza. Zgon cesarza miał nastąpić rano, lecz Agrypina czekała z jego ogłoszeniem aż do południa, by ułatwić Neronowi przejęcie władzy (cf. Suet. Claud. 44-5, Nero 8). 
pokojem, że s-pokoju nie dają nawet godzinom południowym. A ty tę wspaniałą porę dnia, marnując taką okazję, ot tak sobie pominiesz?"'

Niech ci będzie:

[4] Już Feb nieba połowę wydzielił w swej drodze i ciągnie, bliżej zmierzchu, zmęczony za wodze, jasność śląc po pochyłej przestworzy podłodze.

3. [1] Klaudiusz zaczął zionąć ducha, ale, nie wiedząc którędy, wyzionąć nie umiał. Wtedy Merkury, jako że zawsze miał wielkie upodobanie w jego wrodzonych talentach umysłowych ${ }^{26}$, wziął na bok jedną z trzech Parek ${ }^{27}$ i mówi: „Czemu, okrutnico, pozwalasz, by biedak tak się męczył? Czy po tylu udrękach w końcu umrze? Już od sześćdziesięciu czterech lat walczy... z życiem. Czemu ty tak źle życzysz jemu i całemu państwu? [2] Pozwól choć raz mieć słuszność astrologom - uśmiercali go wszak każdego roku, każdego miesiąca, odkąd został cesarzem ${ }^{28}$. Choć i tak nic dziwnego, że się mylą w jego horoskopie i nie znają jego ostatniej godziny: on zawsze sprawiał wrażenie, że się dzisiaj urodził. Rób, co do ciebie należy:

Srogiej śmierci go wydać nawet się nie wahaj

Lepszy na pustym tronie zasiądzie monarcha" ${ }^{29 "}$.

[3] A Kloto na to: „Cholipka! Ja chciałam dać mu jeszcze troszeńkę czasu, by zdążył nadać obywatelstwo tej garsteczce, która została (uparł się przecież, że na wszystkich Greków, Gallów, Hiszpanów i Brytów nałoży rzymskie togiiº).

\footnotetext{
${ }^{26}$ Nieprzypadkowo tuż przed śmiercią Klaudiusza pojawia się Merkury, boski posłaniec, ale także przewodnik dusz w drodze do podziemi (odpowiednik greckiego Hermesa psychopomposa). Jako bóg znany ze swej pomysłowości i podstępów, musiał z przymrużeniem oka traktować intelekt cesarza konsekwentnie przedstawianego przez Senekę jako głupca.

${ }^{27}$ Trzy siostry, podobnie jak greckie Mojry, personifikacje ludzkiego losu. Atropos snuła nić życia każdego śmiertelnika, Kloto ją naciągała, a Lachezis przecinała w momencie śmierci.

${ }^{28}$ Astrologowie (zwani w starożytności mathematici lub Chaldaei) w dobie burzliwych stosunków politycznych okresu cesarstwa często byli wykorzystywani do przepowiadania dnia śmierci władcy. Furiusz Skribonianus za takie pytanie skierowane do ludzi parających się tym zawodem został nawet wypędzony, a z nim na mocy nieskutecznej uchwały senatu Italię mieli opuścić także mathematici (Tac. Ann. XII 52).

${ }^{29}$ Cytat z Wergiliusza (Georg. IV 90), w oryginale będący poradą dla pszczelarza (w parodii stylu epickiego), co robić z upadłym „królem” roju. Seneka zgrabnie wykorzystuje ten ustęp w kontekście śmierci Klaudiusza i wstąpienia na tron nadziei narodu - Nerona.

${ }^{30}$ Aluzja do planów objęcia prawami obywatelskimi także mieszkańców prowincji. Brytowie, Galowie i Hiszpanie byli w oczach Rzymian barbarzyńcami, przez co zrównanie ich statusu spotykało się z ostrym sprzeciwem zwłaszcza stanu senatorskiego (cf. Tac. Annales, XI 23-5).
} 
Ale skoro trzeba też zostawić paru cudzoziemców na chów... i ty tak rozkazujesz - niech się stanie!". [4] Po czym otwiera puzderko i wyciąga trzy nici: jed-na była Au-gu-ry-na, dru-ga Ba-bu-sa, trze-cia Klau-diu-sza ${ }^{31}$. „Tym trzem - powiada - każę umrzeć tego samego roku, w krótkich odstępach czasu po sobie - nie puszczę naszego cesarza bez towarzystwa! Nie wypada przecież, by człowiek, który do niedawna widział tyle tysięcy ludzi podążających za nim, tyle postępujących przed nim, tyle tłoczących się wokół niego ${ }^{32}$, nagle miał zostać sam. Tymczasem zadowoli się tymi dwoma kompanami”.

4. [1] Tak rzecze i, nić kręcąc na szpetnym wrzecionie, błazeńskiego władania cięciem czyni koniec.

A Lachezis przybrana, w upiętym warkoczu, Z wieńcem z Pierii na włosach, nieco wyżej oczu ${ }^{33}$

Białej uszczknęła przędzy ze śnieżnego runa, By ułożyć ją dłonią, skąd dobra fortuna.

Wtem wełna zmienia kolor - dziwują się siostry:

Pośledniej przędzy nitki metalem obrosły!

Złote wieki zstępują z pięknego wrzeciona,

Przędą pomyślną wełnę, co jest nieskończona, i cieszą się, gdy pełne lubej pracy ręce.

Sama robota idzie: bez trudu wciąż więcej

$\mathrm{Z}$ wijącej szpuli schodzi nici miękkich, nowych:

Titona i Nestora ${ }^{34}$ przeżyją wiekowych.

Feb też pieśnią pomaga, przyszłą radość głosi

Już to - wesół - przygrywa, już to wełnę nosi.

Pieśnią siostry zajmuje, by znoju nie znały.

${ }^{31} \mathrm{~W}$ oryginale imiona Augurinus, Baba prawdopodobnie nie należą do żadnych konkretnych osób. Auguryn może być aluzją do sprawowanego przez Klaudiusza urzędu augura, Baba zdaje się funkcjonować jako imię przysłowiowego głupka oraz kojarzyć się z jąkaniem (łac. balbus „jąkała”) - obaj towarzyszą w godzinie śmierci Klaudiuszowi (łac. claudere - „kuleć”). Ustęp może też być początkiem dziecięcej wyliczanki mającej u podstaw trzy pierwsze litery alfabetu (A..., B..., C...), co spróbowaliśmy oddać rytmicznie (stąd modyfikacja imienia Baby na Babusa).

${ }^{32}$ Chodzi zapewne o pochód triumfalny, który Klaudiusz odbył po zwycięstwie w Brytanii w roku 44. Teraz cesarza czeka kolejny „Zwycięski” marsz ku - przez wszystkich oczekiwanej śmierci i również w tej drodze nie będzie pozostawiony sam.

${ }^{33}$ Kolejna Parka, Lachezis, została tutaj przedstawiona jako młoda dziewczyna z włosami zaplecionymi jak u dziewiczej westalki. Dodatkowo bogini losu nosi na głowie wieniec z pieryjskiego wawrzynu, który jest ściśle kojarzony z Apollonem i jego podopiecznymi - muzami. Takie wcielenie Parki ma przypominać o artystycznych aspiracjach młodego Nerona.

${ }^{34}$ Obie postaci dożyły sędziwego wieku. Nestor to najstarszy wojownik pod Troją (Hom. Il. I 252), podczas gdy Titonos był kochankiem Eos, która podarowała mu wieczne życie, zapomniawszy o wiecznej młodości. Imiona te funkcjonują jako przysłowiowe oznaczenie długowieczności (podobnie jak w naszym kręgu kulturowym biblijny Matuzalem). 
A gdy muzyce brata nie szczędzą pochwały, ponad człowieczą miarę tkają nić swą starki - wśród pochlebstw rośnie dzieło. „Nie skracajcie, Parki, jego życia” Feb na to „Niech przyćmi śmiertelnych:

on jak ja pełen wdzięku, i z twarzy subtelny, i śpiew jego nie gorsze niźli mój ma brzmienie, błogi czas da zmęczonym, przerwie praw milczenie. Jak poranny Lucyfer, co rozpędza gwiazdy lub, gdy wrócą wieczorem, jak Hesperus jasny ${ }^{35}$, on jak promienne Słońce, gdy z samego rana Aurora dzień sprowadzi w czerwienie odziana, Słońce, swój rydwan nagląc, patrzy w dół na ziemię, Taki nastanie Cezar, ujrzy rzymskie plemię takiego to Nerona. Jasność z twarzy bije, kształtną mu kędziory zalewają szyję.

[2] Tyle Apollo. A Lachezis, jako że sama również sprzyjała temu bardzo przystojnemu mężczyźnie, nie żałowała Neronowi i od siebie dodała mu wiele lat życia. Co do Klaudiusza natomiast, rozkazują, by go

wśród okrzyków ciżba radosna na marach z pałacu wyniosła ${ }^{36}$

Bo i faktycznie on już zdołał wypuścić... ducha i w tym momencie zakończył ten swój pozór żywota. Zszedł zaś, przysłuchując się występowi komików ${ }^{37}$ (tak że wiedz, że nie bez powodu się ich boję!). [3] Jego ostatnie słowa, jakie dały się słyszeć wśród żywych (chociaż potężniejszy dźwięk wydobył tą częścią ciała, którą łatwiej było mu cokolwiek wy-bąkać), były takie: „A niech mnie! Cały się, chyba, ufajdałem". Czy wtedy się ufajdał, nie wiem; ale na pewno dla kraju g... zrobit.

${ }^{35}$ Zarówno Lycyfer (łac. 'niosący światło', cf. gr. Phósphoros), jak i Hesperus są antycznymi nazwami planety Wenus, opisywanej jako najdłużej widziana gwiazda - odpowiednio - poranna i wieczorna.

${ }^{36}$ Cytat z zachowanego fragmentu sztuki Eurypidesa Cresphontes (Fr. 449. 4 Nauck). W greckim oryginale przewrotnie opisano moment narodzin człowieka jako czas smutku w perspektywie przyszłych strapień, zalecając jednocześnie reagować radośnie na zgon, kiedy zmarły uwalnia się od wszelkich cierpień. Seneka sarkastycznie wykorzystuje ten paradoks do opisu powszechnej euforii w chwili śmierci Klaudiusza.

${ }^{37}$ Seneka przemyca szczegół z historycznych okoliczności śmierci Klaudiusza, zgodny z relacją Swetoniusza o występie komediantów przed zmarłym cesarzem, którzy mieli odwrócić uwagę od jego zgonu (Claud. 45). 
SÉNECA, APOCOLOCÍNTOSIS 1-4. LA „MUERTE DEL DIVINO CLAUDIO”

Resumen

El articulo ofrece una traducción al polaco del inicio de la Apocolocintosis de Séneca el Joven (Apoc. 1-4), que, aparte del prólogo del narrador, contiene la descripción de la muerte de Claudio. El texto polaco trata de seguir, consecuentemente, el modelo de prosimetrum del original, atendiendo, a la vez, al potencial cómico de la sátira senequiana. A la traducción, además, le acompañan unas notas a pie de página de carácter explicativo, un breve comentario filológico y una introducción de parte del traductor. 